\title{
Article \\ How Do Alliance Portfolio Factors Affect a Precision Medicine Firm's Innovation Performance?
}

\author{
Yucheong Chon ${ }^{1}$ and Kwangsoo Shin ${ }^{2, *}$ \\ 1 Technology Management, Economics, and Policy Graduate Program (TEMEP), Seoul National University, \\ Seoul 08826, Korea; ycchon@snu.ac.kr \\ 2 Department of Biomedical Convergence, College of Medicine, Chungbuk National University, Chungdae-ro 1, \\ Seowon-gu, Cheongju 28644, Korea \\ * Correspondence: sksidea@chungbuk.ac.kr or sksidea@gmail.com
}

Citation: Chon, Y.; Shin, K. How Do Alliance Portfolio Factors Affect a Precision Medicine Firm's Innovation Performance? J. Open Innov. Technol. Mark. Complex. 2021, 7, 203. https:// doi.org/10.3390/joitmc7030203

Academic Editors: JinHyo

Joseph Yun, Lei Ma and

Sungyong Choi

Received: 15 August 2021

Accepted: 8 September 2021

Published: 13 September 2021

Publisher's Note: MDPI stays neutral with regard to jurisdictional claims in published maps and institutional affiliations.

Copyright: (c) 2021 by the authors. Licensee MDPI, Basel, Switzerland. This article is an open access article distributed under the terms and conditions of the Creative Commons Attribution (CC BY) license (https:// creativecommons.org/licenses/by/ $4.0 /)$.

\begin{abstract}
Precision medicine is an approach to disease treatment and prevention that seeks to maximize effectiveness by taking into account individual variability in genes, environment, and lifestyle. The medical paradigm has been changed with the emergence of precision medicine and many companies with business related to precision medicine should cooperate with other companies. The purpose of this study is to analyze the alliance portfolio factors that affect firms' innovation performance. This study examined whether the diversity factors of the alliance portfolio and alliance management capability influenced its innovation performance. Additionally, we investigated the moderate effects of participation of research organizations in the alliance portfolio. As a result, there was an inverted U-shaped relationship between the industry diversity of the portfolio and innovation performance; therefore, the participation of research organizations in the alliance portfolio showed a positive effect. Additionally, the value governance diversity changed to have a positive effect by interacting with research organizations. This study provides information on the alliance portfolio factors that affect the innovation performance of precision medicine companies.
\end{abstract}

Keywords: alliance portfolio; alliance diversity; alliance management capability; research organization; innovation performance

\section{Introduction}

Precision medicine is an approach to disease treatment and prevention that seeks to maximize effectiveness by taking into account individual variability in genes, environment, and lifestyle [1]. The medical paradigm has been changed with the emergence of precision medicine [2]. In the past, treating illnesses so that patients could live longer and be healthier was important, but preventing and controlling disease became more important. Technologies and services related to precision medicine include genome analysis equipment, health information measurement equipment, targeted and immune cancer drugs, health information integration and linkage services, genome analysis services, and medical big data analysis [3]. These make it difficult to carry out a business independently by a company with only one technology and service [4]. Therefore, many companies with business related to precision medicine should cooperate with other companies. This means that they should strategically ally with various organizations, and how they manage alliance portfolios will determine the success or failure of the enterprise.

Several researchers have conducted analyses of the alliance portfolio factors that affect corporate performance. They mainly designated single industries such as automotive, biotechnology, and pharmaceuticals [5-7]. However, these studies do not provide how the diversity of alliance portfolios and alliance management capability through alliance experience influences a firm's innovation performance. In addition, the studies provide fragmented knowledge about the moderating effects of each factor, and fail to comprehensively analyze them. Furthermore, in the field of biotechnology, previous studies have been 
important to consider convergence of the technologies and accumulation of the biotechnology [4]. Such convergence transcends the boundaries between industries, and cooperation between organizations through open innovation becomes important, and results in the agenda of a company's alliance portfolio composition and alliance formation capability. However, previous alliance portfolio studies have a limitation in that they were performed in a piecewise manner. In addition, although the cumulative nature of biotechnology is important, there are few studies on the moderating effect of cooperation with research organizations such as universities and government research institutes on alliance portfolios.

Therefore, the purpose of this study is to analyze the alliance portfolio factors that affect firms' innovation performance. It examined whether the diversity factors of the alliance portfolio influenced its innovation performance. In addition, the interactions among these factors and the firm's alliance experience were examined. Furthermore, because this study is related to the biomedical industry, the moderating effect of the alliance with research organization such as university was examined, which was a major factor for innovation performance. For analysis, panel data from 48 companies related to precision medicine services in the United States (hereafter US) was used.

This study can provide information on the alliance portfolio factors that affect the innovation performance of precision medicine companies. The significance of this study is as follows. First, this study extends the scope of previous studies by confirming the interplay between portfolio diversity factors and a firm's alliance experience, which were individually analyzed in previous studies. Second, this study analyzed the role of research organizations when companies formulated an alliance portfolio. Finally, this study gives information about what factors a company should consider in the future to improve its performance as the market environment changed. It also presents the capabilities of companies that will be critical to the success of the portfolios of precision healthcare companies.

From the empirical results, it was suggested that corporate managers need to focus more on the R\&D alliance than on functional diversity to improve innovative performance, and avoid alliances with too various industrial fields because the firms' resources are limited. Additionally, in terms of policy, it is necessary to pay attention to the composition of the alliance portfolio with research institutes as a catalyst for enhancing innovation performance.

This paper is structured as follows. The following section introduces the theoretical background and hypotheses. Section 3 introduces measurements, methods, and models. Section 4 presents the results of empirical analysis. The last section presents a conclusion and remarks on the study.

\section{Background and Hypotheses}

\subsection{Precision Medicine}

The term "precision medicine" was noted by President Obama in 2015 when he announced the Precision Medicine Initiative [2]. However, it had already existed for a relatively long time under the term "personalized medicine" [8].

The definition of personalized medicine varies according to the literature, but conventional medicine is a one-size-fits-all method that applies the same treatment for the same diagnosis in patients, whereas customized medical treatment is personalized according to individual characteristics. It is now common to see this type of treatment applied. The United States President's Council of Advisors on Science and Technology (PCAST) defines personalized medicine as tailoring medical treatment to individual patient characteristics. This means dividing individuals into subgroups based on their likelihood of obtaining a specific disease and responding to a particular treatment. It is possible to concentrate prevention and treatment only in groups that can benefit from it, considering side effects and costs [9]. Price Waterhouse Coopers (PWC) defines customized care as appropriate treatment for the right person at the right time. This is interpreted to mean that genes are still very important factors in human disease and treatment, but there are many other factors to consider, such as environment, lifestyle, and so on [10]. 
The definition of precision medicine was first presented in a National Academy of Sciences report by Susan Desmond-Hellmann and Charles Sawyers of Memorial Sloan Kettering Cancer Center. They defined precision medicine as the use of technology, science, and medical records to better understand the roots of disease and develop targeted therapies to ultimately save people's lives [11]. Since then, the Precision Medicine Initiative (PMI) Working Group introduced a new medical approach to disease prevention and treatment technology, taking into account individual variations in people's genomes, environments, and lifestyles [2]. Precision medicine can be considered to be more specific in the classification of individuals based on genetic, disease, and life information. It can be seen that the concept of personalized medicine is embodied in that it selects an effective treatment method. In addition, precision medicine has evolved into a concept that includes the provision of more preemptive health care services through large-scale genome information analysis [8].

Precision medicine emphasizes the convergence of biotechnology above all else [4]. In particular, the clinical approach of prevention, diagnosis, treatment, and follow-up management based on health data enables a more personalized medical approach as IT technology converges with medical technology. Bio-companies based on one or two major technologies inevitably form strategic alliances due to the convergence of these technologies, which causes problems in the composition and management of alliance portfolios.

\subsection{Functional Diversity of Alliance Portfolio in Value Chain}

Researchers advocating resource-based views have argued that firms could have a competitive advantage when they have scarce and difficult alternatives [12,13]. Companies could use their resources efficiently with their partners while maintaining their own functions through partnerships [14,15]. Therefore, researchers advocating resource-based views have insisted that partnerships are more efficient in utilizing resources than mergers and acquisitions [16,17].

Some studies showed that a firm's innovation performance can be determined by the proportion of R\&D alliances in the portfolio and the alliance governance diversity in its portfolio. An empirical study showed that the higher the portion of R\&D collaboration in the portfolio, the higher the innovation performance of the firm [18]. However, corporate innovation can be created in R\&D as well as in other fields such as production, manufacturing, marketing, and logistics [19]. In particular, in the case of convergence technologies such as precision medical care, innovation is taking place not only through R\&D but also through production and marketing alliances. Convergence technology can be defined as a technology innovation that combines multiple devices or functions within a single platform in a way that adds functional, operational, or economic synergy, and it is expected that the combination of these technologies will show more improved effects [20]. Precision medicine would not be achieved through the development of a single technology, and it is necessary to develop a cohort, integrated precision medical information system, genome analysis diagnosis treatment method, artificial intelligence-based diagnosis treatment technology, and device development for health management services [11,21]. In terms of being able to provide, it could be said to be a convergence technology. However, in the case of companies related to precision medicine, there are cases where they have expertise in specific technologies, so they select partnerships for technology development in other fields [4]; for example, a bio company to have better Information Technology (IT).

There was a study that showed that when the contract motivations of alliances in the portfolio (R\&D, manufacturing, marketing, etc.) were diverse, the innovation performance of the company was higher, because it enabled various innovations in value chains from R\&D to manufacturing and marketing [6]. Although these results were clearly contradictory, this study assumed that various functional innovations in the value chain can be created. Therefore, this study verifies the following hypothesis. 
Hypothesis 1. Functional diversity of alliance portfolio in value chain positively influence the focal firm's innovation performance.

\subsection{Industrial Diversity of Alliance Portfolio}

Some empirical studies have analyzed the effects of industrial diversity on alliance portfolios. The first showed that industry diversity in an alliance portfolio positively affected a firm's performance. There was a study that argued that firms with different industry backgrounds could acquire resources and skills from one another [22]. Additionally, researchers argued that alliances with companies with different industry backgrounds could provide opportunities to learn new skills $[23,24]$. In addition, partnerships with companies with different industry backgrounds could provide access to different knowledge and technology bases and exploit new business opportunities [25]. The second type of study showed that the diversity of industries within an alliance portfolio had a negative effect on firm performance.

If the focal firm was not familiar with its partners' industries, it could have a significantly lower ability to learn [26]. Additionally, alliances with partners in other industries were likely to cause management problems because of their unfamiliarity [27]. Some researchers suggested that the diversity of industries within an alliance portfolio had a U-shaped effect on firm performance. Other researchers suggested that the diversity of the alliance partner industries affected the performance of the focal firm, in the form of an inverted U-shape [28]. The empirical study that analyzed 138 companies in the global automobile industry for 20 years (1985-2005) found that as the industries in the portfolio diversified, the performance of companies declined in the early stage and then increased after a certain point [3]. On the contrary, some researchers insisted that there was an inverted U-shaped relationship between partners' industrial backgrounds and the focal firm's performance [29-31]. Therefore, this study verifies the following hypothesis.

Hypothesis 2. There is an inverted U-shaped relationship between the diversity of partners' industries and the focal firm's innovation performance.

\subsection{Alliance Management Capability in Alliance Portfolio}

Researchers have argued that alliance management capability affects the success of an alliance portfolio. In order for companies to maintain knowledge through collaboration with partners, they need the ability to connect. This ability to connect is also related to the relationship ability of alliances and a firms' relational capacities [32]. The alliance management ability affects not only the success of the individual alliance, but also overall portfolio management ability by managing multiple alliances [33]. Researchers insisted that the ability of a company to manage its alliance is also important for companies to manage knowledge. Companies can develop their ability to manage alliances through knowledge which was gained by participating in the former alliance [34].

Other researchers have argued that the more alliance experience the focal firm has, the greater the alliance management capacity it can build, which could lead to the success of the partnership [35-37]. They insisted that companies that had more alliance experience could respond flexibly to management risks that may arise during the partnership process [36]. Additionally, the alliance experience has the effect of positively moderating R\&D alliances and new product development in high-tech companies with data of $2226 \mathrm{R} \& \mathrm{D}$ alliances of 325 global biotechnology firms [37]. In the case of pharmaceutical companies, the general alliance experience has proven to be effective in increasing joint R\&D project performance, even if not necessarily a partner-specific experience [35].

In addition, companies could grow their abilities and overcome trade-offs from formal alliance experience [38]. Firms could increase benefits from diverse experiences that companies receive from their alliances, and mitigate the risk from Alliance Portfolio Diversity (APD) [39]. Additionally, partnership experience had a positive impact on acquisition results, as it affected corporate organizational knowledge and ability to be enhanced [40]. 
Alliance data of pharmaceutical companies were analyzed, and the formation of simultaneous alliances could have a negative impact on the company's performance, but that such negative effects could be mitigated if allied with experience [41]. Therefore, this study verifies the following hypothesis.

Hypothesis 3. Alliance management capability in alliance portfolios positively influences the focal firm's innovation performance.

\subsection{The Moderating Effect of Research Organizations in Alliance Portfolio}

Previous studies have found that partnerships with research organizations such as universities can have more positive effects on innovation performance than partnerships with other organizations. Strategic alliances between firms and research organizations play a key role in the creation and application of knowledge for new products, technology development or business models [42]. The effect of star scientists in research organizations on technological innovation is of paramount importance in the biomedical industry [43]. Furthermore, this is also because the knowledge accumulated in the research organization for a long time can positively affect the innovation performance of the cooperation [1]. For example, firms with alliances with research organizations such as universities have better innovation performance than those without $[5,37]$. There was an empirical study that This study asserts that relationships with universities and other higher education institutions have a positive and significant impact on the innovative development of enterprises [44].

Therefore, this study verifies the following hypotheses.

Hypothesis 4a. The alliance with the research organization positively moderates the impact of functional diversity of the alliance portfolio in value chains on innovation performance.

Hypothesis $4 \mathrm{~b}$. The alliance with the research organization positively moderates the impact of industrial diversity of the alliance portfolios on innovation performance.

Hypothesis 4c. The alliance with the research organization positively moderates the impact of focal firm's alliance management capability on innovation performance.

The research model for hypotheses can be expressed as Figure 1.

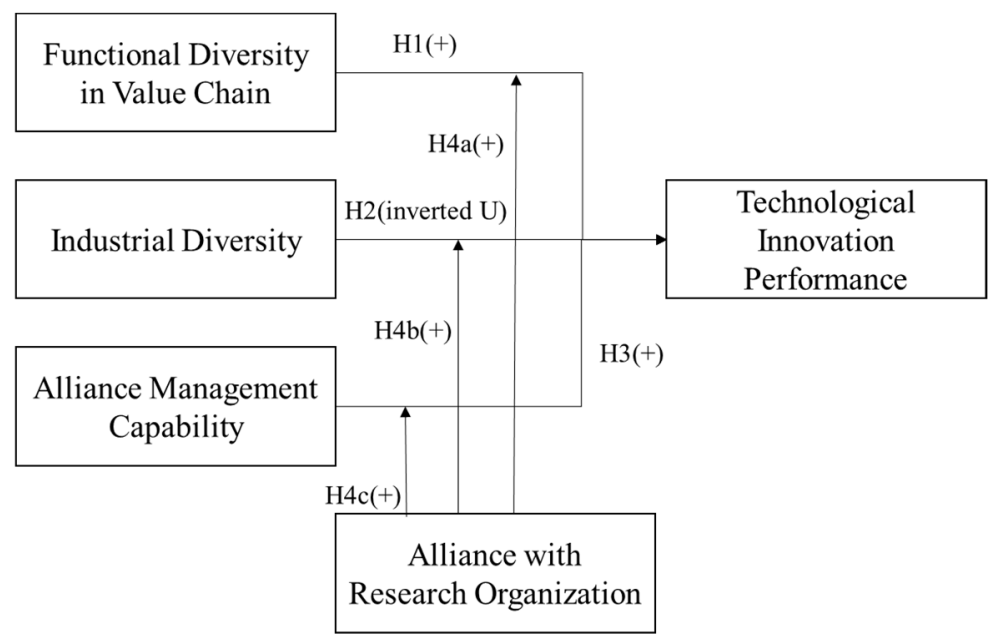

Figure 1. Framework of the study.

\section{Method}

\subsection{Data}

In this study, 10 years of contract (alliance) data (2003-2012) of firms in the precision medicine industry were used for analysis. During this period, in the trend of personalized 
medicine, many new companies for precision medicine based on genomic and clinical information are established in the United States, and existing pharmaceutical companies are also creating new departments related to precision medicine or switching their business models to this field [3]. The alliance data were collected from the Life Science Analytics Medtrack database. This database provides information on strategic alliances and Mergers and Acquisitions (M\&A) of biotechnology, pharmaceutical, medical information, and medical device companies from 1960 to the present. From the Medtrack database, precision medicine-related keywords (Table 1 ) that were derived from the literature $[11,45,46]$ were searched. The information of alliance portfolios was the number of partners, deal (contract) title, deal type, contract summary, and contract conditions. Additionally, financial data of firms were collected from the Wharton Research Data Services (WRDS) database and the Bureau van Dijk Orbis database. The financial information was the age, number of employees, and sales and operating revenue of the focal firm and Standard Industrial Classification (SIC) codes of the firm and its partners.

Table 1. Keywords related to precision medicine.

\begin{tabular}{l} 
Keywords \\
\hline Big data, Biobank, Biosamples, Candidate gene, Common data mode (CDM), \\
Chimeric antigen receptor, Chromosomal translocation, Clinical utility, Cloud, \\
Cohort, CRISPR, Crowdsourcing, Database of Genotypes and Phenotypes (dbGap), \\
Data-intensive, biology, Decision-support systems, Disease marker, Disease risk, \\
Disease taxonomy, EHR-derived phenotype, Electronic health record (EHR), \\
Electronic medical records, Epigenetic, Epigenome, Epiphenomenon, Etiology, \\
Exposome, Gel electrophoresis, GenBank, Gene expression, Gene-environment \\
interactions, Genetic data, Genetic privacy, Genome editing, Genome-wide \\
association study, Genotype, Geographic information system, Health Insurance \\
Portability and Accountability Act (HIPAA), Health kit, Heterozygous, Health \\
information system (HIS), Human Microbiome Project, IoT, Cloud, Bigdata, and \\
Mobile (ICBM), Institutional Review Board, International Classification of \\
Diseases, Internet of Things (IoT), Keytruda, Lifelog, Lifestyle, Lipidome, \\
Metabolic profiling, Metabolome, Microbiome, Molecular biology, Natural \\
language procession, Next-generation sequencing (NGS), Ontology, \\
Oophorectomy, Pathogenesis, Pathology, Pathophysiology, Personalized, \\
Pharmacogenetics, Phenotype, Phenotype-genotype association, Precision, \\
Precompetitive collaboration, Proteome, Radioisotopic labeling, Recombinant \\
DNA, Sequelae, Signs and symptoms, Single nucleotide polymorphism, \\
Single-molecule, sequencing, Smart phone, Social network, Systematized \\
Nomenclature of Medicine (SNOMED), Transcription activator-like effector \\
nuclease (TALEN), Transcriptome, Wearable device, Web platform, Whole-genome \\
sequencing, Zinc finger
\end{tabular}

Eighty-two keywords related to precision medicine were searched and collected with related company information from Medtrack. Duplicated companies and some companies that did not have any alliance information from 2003 to 2012 were excluded. Additionally, companies that were not registered in the WRDS or Orbis database were excluded and for which financial information could not be confirmed. As a result, 48 companies in the US were used in the empirical research. Those companies had 305 alliances with a total of 377 partners over the past 10 years. The number of alliances was smaller than the number of partners, because multiple alliances participated in one alliance portfolio.

\subsection{Variables}

\subsubsection{Dependent Variable}

The number of patents can be seen as an innovation result and reflect inventive activities [47]. The number of patents as the sum of patents registered were driven in the United States (United States Patent and Trademark Office (USPTO) database), the EU (Espacenet database), and China and Japan (Korea Intellectual Property Rights Information 
Service (KIPRIS) database). However, the number of patents has a certain lag from the time of measuring the independent variable, considering the period when the influence of the independent variables is reflected. Previous studies argued that there was a time difference of 1-4 years between the time of investing in R\&D and the time of patent registration. Studies in the 2000s and earlier insisted that it took 3-4 years to register patents. There was a study that analyzed the time difference between the input of R\&D and the time of patent registration for 157 companies in 7 US industries, and there was a gap of 4 years [48]. The time delay effects of R\&D inputs and patents over 4 years, and the estimated coefficients were high [49]. However, these studies had a limitation, because they did not consider statistical problems such as multicollinearity and autocorrelation [50]. Recent studies insisted that the time lag between R\&D investment and patent creation or sales increase was from less than 1 year to 2 years. The time lag between R\&D investment, patent creation, and sales growth by industry was $1-2$ years [50]. The study that analyzed 51 pharmaceutical companies and found that the time difference between R\&D input and patent application was less than 1 year [51]. In this study, a 1-year lag was set based on previous reports.

\subsubsection{Independent Variables}

The empirical analysis included 4 independent variables: functional diversity in value chain, industrial diversity, and alliance management capability.

The variable of functional diversity in the value chain was the Herfindal-Hirschman Index (HHI) of deal types. Since one alliance portfolio contained more than one type of contract, the alliance functions were divided into 5 groups in consideration of Gulati's alliance classification standard [52] and deal types of the Medtrack database. Group 1 was R\&D alliances related to patents such as licensing agreements, options, and sublicenses. Group 2 was R\&D alliances such as collaborations, development, and co-development. Group 3 was manufacturing and sales alliances such as co-marketing, co-promotion, and manufacturing. Group 4 was ownership purchases, such as acquisitions. The last group was other alliances. The HHI of alliance types in the portfolio was measured to find the functional diversity in the value chain.

The industrial diversity variable was the HHI of the focal firm and its partners' Standard Industrial Classification (SIC) codes, calculated from the SIC codes of the focal firm and partners in the portfolio. In the WRDS database, companies are classified according to their SIC (for example, 4714, 4711, 4751, 4713, 4715), and can be classified into 5 categories (0 to 4 ). In this classification, 4 means that the 4 digits of the SIC code are the same, 3 means that 3 digits are the same, and 0 means that no digits are the same. HHI values were then calculated using these values.

The variable of alliance management capability was set to the number of the focal firm's cumulative alliances. The sum of the number of alliances from the beginning of the data to year $(t-1)$ of the alliance portfolio was used.

In this study, dummy variables for alliance with a research organization was used to decide whether there was participation by universities or governments. The university dummy variable was set to 1 if there was a university among the partners, and 0 if there was no university. The government dummy variable was set to 1 if there was a government or governmental institute among the partners and 0 if there was not.

\subsubsection{Control Variables}

The first control variable was firm size, as the larger the size of a focal firm, the more performance it can generate. Firm size was set as operating revenue [53,54]. In addition, the age of the focal firm was included. As old companies can accumulate more stocks than young companies, the business performance of an older firm would be more than that of a younger firm [55-58]. Finally, since the dependent variable was the number of patents; the R\&D expenditure of the firm was set as the control variable. This is because companies with high R\&D investment can generate more patents [7,30,59]. 
The variables mentioned above are summarized in Table 2.

Table 2. Describes the variable descriptions and data sources.

\begin{tabular}{|c|c|c|c|c|c|}
\hline & & Variables & & Sources & Database \\
\hline $\begin{array}{l}\text { Dependent } \\
\text { variable }\end{array}$ & Patent & $\begin{array}{l}\text { Number of patents } \\
\text { (innovation } \\
\text { performance) }\end{array}$ & $\begin{array}{l}\text { Number of patents } \\
\text { in US, EU, China, } \\
\text { and Japan in year } \\
(t+1)\end{array}$ & $\begin{array}{c}\text { Baum et al. [60] } \\
\text { Reuer et al. [61] } \\
\text { Pakes and Griliches [49] } \\
\text { Mowery et al. [62] }\end{array}$ & $\begin{array}{c}\text { United States Patent and } \\
\text { Trademark Office } \\
\text { (USPTO), Espacenet, } \\
\text { Korea Intellectual } \\
\text { Property Rights } \\
\text { Information Service } \\
\text { (KIPRIS) }\end{array}$ \\
\hline \multirow{4}{*}{$\begin{array}{l}\text { Independent } \\
\text { variables }\end{array}$} & Form & $\begin{array}{c}\text { Functional } \\
\text { diversity in value } \\
\text { chain }\end{array}$ & $\begin{array}{l}\text { Herfindal- } \\
\text { Hirschman Index } \\
\text { (HHI) of alliance } \\
\text { portfolio using } \\
\text { contract types }\end{array}$ & $\begin{array}{l}\text { Lin et al. [18] } \\
\text { Hagedoorn and } \\
\text { Schakenraad [63] } \\
\text { George et al. [5] }\end{array}$ & Medtrack \\
\hline & Industry & Industrial diversity & $\begin{array}{l}\text { HHI of alliance } \\
\text { portfolio using } \\
\text { focal firm and } \\
\text { partners' Standard } \\
\text { Industrial } \\
\text { Classification (SIC) } \\
\text { codes }\end{array}$ & $\begin{array}{c}\text { Hamel et al. [22] } \\
\text { Nelson [23] } \\
\text { Rumelt et al. [24] } \\
\text { Dussauge et al. [25] } \\
\text { Santoro and McGill [26] } \\
\text { Roth and O'Donnell [27] } \\
\text { Goerzen and Beamish [28] } \\
\text { Jiang et al. [6] }\end{array}$ & $\begin{array}{l}\text { Wharton Research Data } \\
\text { Services (WRDS), } \\
\text { Medtrack }\end{array}$ \\
\hline & Experience & $\begin{array}{l}\text { Firm's alliance } \\
\text { management } \\
\text { capability }\end{array}$ & $\begin{array}{l}\text { Number of } \\
\text { cumulative } \\
\text { alliances }\end{array}$ & $\begin{array}{c}\text { Gulati [52] } \\
\text { McGee and Dowling [64] } \\
\text { McGee et al. [65] } \\
\text { Mitchel et al. [66] }\end{array}$ & Medtrack \\
\hline & $\begin{array}{l}\text { Research } \\
\text { organization }\end{array}$ & $\begin{array}{l}\text { Whether a } \\
\text { university or } \\
\text { government } \\
\text { participated }\end{array}$ & $\begin{array}{l}\text { Whether a } \\
\text { university or } \\
\text { government } \\
\text { participated in } \\
\text { alliance portfolio } \\
\text { (dummy variable) }\end{array}$ & $\begin{array}{l}\text { George et al. [5] } \\
\text { Rothaermel and Deeds [37] }\end{array}$ & Medtrack \\
\hline \multirow{3}{*}{$\begin{array}{c}\text { Control } \\
\text { variables }\end{array}$} & Size & $\begin{array}{l}\text { Firm's operating } \\
\text { revenue }\end{array}$ & $\begin{array}{l}\text { Firm's operating } \\
\text { revenue in year t } \\
\text { (million dollar, log) }\end{array}$ & $\begin{array}{l}\text { Lee [53] } \\
\text { Champonnois [54] }\end{array}$ & Medtrack, WRDS, Orbis \\
\hline & Age & Firm's age & $\begin{array}{l}\text { Years from date of } \\
\text { incorporation } \\
\text { (year) }\end{array}$ & $\begin{array}{c}\text { Thornhill and Amit [55] } \\
\text { Gittelman and Kogut [56] } \\
\text { Lahiri and Narayanan [57] } \\
\text { Leeuw et al. [58] }\end{array}$ & Medtrack, WRDS, Orbis \\
\hline & RD_exp & R\&D investment & $\begin{array}{c}\text { Firm's R\&D } \\
\text { investment in year } \\
\text { t (million dollar, } \\
\log )\end{array}$ & $\begin{array}{l}\text { Wuyts and Dutta [7] } \\
\text { Huang et al. [59] }\end{array}$ & Medtrack, WRDS, Orbis \\
\hline
\end{tabular}

\subsection{Model}

Negative binomial regression was used in this study to analyze the impact of the components of the alliance portfolio on a firm's innovation performance. Negative binomial regression was used, because the dependent variable is an integer as the number of patent registrations and the value is biased toward zero, so it follows the Poisson distribution. Statistical errors were more likely to occur when dependent variables with these characteristics were analyzed by multiple regression analysis based on normal distribution. Most of the prior research using the number of patents as a dependent variable used negative binomial regression [67]. As an extension of the Poisson regression, negative binomial regression was used to evaluate models that calculated the occurrence of events when 
extra-Poisson variation goes out in the form of events and over-dispersion. In the negative binomial model of this study, the probability that the patent would be registered was as follows:

Model 1:

$$
\text { patent }_{i,(t+1)}=\beta_{0}+\beta_{1} \text { size }_{i, t}+\beta_{2} \text { age }_{i, t}+\beta_{3} \text { rd_exp } i, t+\varepsilon_{i, t}
$$

Model 2:

$$
\text { patent }_{i,(t+1)}=\beta_{0}+\beta_{1} \text { form }_{i, t}+\beta_{2} \text { research organization } i, t+\beta_{3} \text { size }_{i, t}+\beta_{4} \text { age }_{i, t}+\beta_{5} r \text { exp }_{i, t}+\varepsilon_{i, t}
$$

Model 3:

$$
\text { patent }_{i,(t+1)}=\beta_{0}+\beta_{1} \text { industry }_{i, t}^{2}+\beta_{2} \text { industry }_{i, t}+\beta_{3} \text { researchorganization }_{i, t}+\beta_{4} \text { size }_{i, t}+\beta_{5} \text { age }_{i, t}+\beta_{6} r \text { exp }_{i, t}+\varepsilon_{i, t}
$$

Model 4:

$$
\text { patent }_{i,(t+1)}=\beta_{0}+\beta_{1} \text { experience }_{i, t}+\beta_{2} \text { research organization }_{i, t}+\beta_{3} \text { size }_{i, t}+\beta_{4} \text { age }_{i, t}+\beta_{5} r \text { rdexp }_{i, t}+\varepsilon_{i, t}
$$

Model 5:

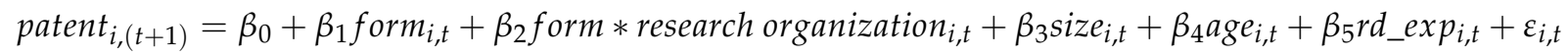

Model 6:

$$
\text { patent }_{i,(t+1)}=\beta_{0}+\beta_{1} \text { industry }_{i, t}+\beta_{2} \text { industry } * \text { research organization }{ }_{i, t}+\beta_{3} \text { size }_{i, t}+\beta_{4} \text { age }_{i, t}+\beta_{5} r d_{-} \text {exp }_{i, t}+\varepsilon_{i, t}
$$

Model 7:

patent $_{i,(t+1)}=\beta_{0}+\beta_{1}$ experience $_{i, t}+\beta_{2}$ experience $*$ research organization $_{i, t}+\beta_{3}$ size $_{i, t}+\beta_{4} a_{\text {age }} e_{i, t}+\beta_{5} r$ rexp $_{i, t}+\varepsilon_{i, t}$

where $i$ is the number of firms $(1,2, \ldots 48)$ and $t$ is the year $(2003,2004, \ldots 2012)$.

The panel data analysis was divided into a fixed effect model, which assumes the inherent characteristics of the firm as a constant term, and a random effect model, which assumes it as a random variable. In this study, the random effect model was applied. For the empirical analysis, Stata 14.2, a program that is widely used for metric model analysis, was used. Even though the version of Stata used in this study was not the most recent version, there was no problem to analyze the panel data.

\section{Results and Discussion}

Table 3 shows the basic statistics of mean, standard deviation, and correlation among variables included in the study model before the regression analysis for the hypothesis test. The correlation table in Table 3 presents significant correlations for all variables except for (1) between "size" variable and all independent variables, (2) between "age" variable and "industry", "research organization", (3) between "RD exp" variable and "industry", and "research organization". Table 4 shows the results of the regression analysis. Model 1 was the result of the basic model analyzed with only the control variables. The innovation performance of the firm was positively related to the size of the firm and the amount of R\&D investment ( $p<0.05, p<0.01$, respectively). In other words, the larger the size of the firm, the more innovation performance. Additionally, the greater the investment in $R \& D$, the more patents were registered. Researchers also insisted that there was a positive influence of firm size and R\&D investment on a firm's innovation performance $[7,30]$. The larger the size of the firm, the more resources it possesses, and the more the R\&D investment, the more active the innovation activity, which was interpreted as positively influencing the innovation performance. On the other hand, the age of the firm does not have a significant effect on innovation performance. 
Table 3. Subject characteristics and correlations among variables.

\begin{tabular}{|c|c|c|c|c|c|c|c|c|c|c|c|c|c|c|}
\hline Variable & Mean & $\begin{array}{l}\text { Standard } \\
\text { Deviation }\end{array}$ & \multicolumn{2}{|c|}{ Form } & \multicolumn{2}{|c|}{ Industry } & \multicolumn{2}{|c|}{ Experience } & $\begin{array}{c}\text { Research } \\
\text { Organization }\end{array}$ & \multicolumn{2}{|c|}{ Size } & Age & \multicolumn{2}{|c|}{ RD_exp } \\
\hline & 0.070 & 0.130 & 1 & & 1 & & & & & & & & & \\
\hline $\begin{array}{l}\text { Industry } \\
\text { Experience }\end{array}$ & $\begin{array}{l}0.293 \\
6.197\end{array}$ & $\begin{array}{l}0.440 \\
12.704\end{array}$ & $\begin{array}{l}0.582 \\
0.479\end{array}$ & $* * *$ & 0.357 & $* * *$ & 1 & & & & & & & \\
\hline $\begin{array}{l}\text { Research } \\
\text { nanization }\end{array}$ & 0.042 & 0.202 & 0.345 & $* * *$ & 0.329 & $* * *$ & 0.193 & $* * *$ & 1 & & & & & \\
\hline Size & 4.362 & 3.966 & 0.066 & & 0.016 & & 0.154 & & 0.027 & 1 & & & & \\
\hline Age & 27.348 & 29.486 & 0.080 & * & 0.016 & & 0.326 & $* * *$ & $0 . \overline{0} 02$ & 0.617 & $* * *$ & & 1 & \\
\hline RD_exp & 2.400 & 2.282 & 0.094 & * & 0.040 & & 0.383 & $* * *$ & $0 . \overline{0}$ & 0.803 & $* * *$ & 0.422 & $* * *$ & 1 \\
\hline
\end{tabular}

${ }^{* * *} p<0.01, * p<0.1$

Table 4. Results of negative binomial analysis.

\begin{tabular}{|c|c|c|c|c|c|c|c|}
\hline Variable & Model 1 & Model 2 & Model 3 & Model 4 & Model 5 & Model 6 & Model 7 \\
\hline Form & & $\begin{array}{l}-0.630^{* *} \\
(0.282)\end{array}$ & & & $\begin{array}{l}-0.629^{* *} \\
(0.285)\end{array}$ & & \\
\hline$(\text { Industry })^{2}$ & & & $\begin{array}{l}-1.730 * * \\
(0.859)\end{array}$ & & & & \\
\hline Industry & & & $\begin{array}{l}1.501^{*} \\
(0.863)\end{array}$ & & & $\begin{array}{l}-0.218 * \\
(0.113)\end{array}$ & \\
\hline Experience & & & & $\begin{array}{l}0.078^{* * *} \\
(0.025)\end{array}$ & & & $0.072(0.077)$ \\
\hline Research organization & & $\begin{array}{l}0.398 * * \\
(0.198)\end{array}$ & $\begin{array}{l}0.388^{* *} \\
(0.184)\end{array}$ & $\begin{array}{l}0.322 * \\
(0.187)\end{array}$ & & & \\
\hline $\begin{array}{l}\text { Form }{ }^{*} \text { research } \\
\text { organization }\end{array}$ & & & & & $\begin{array}{l}0.548^{*} \\
(0.296)\end{array}$ & & \\
\hline $\begin{array}{l}\text { Industry* research } \\
\text { organization }\end{array}$ & & & & & & $0.304(0.206)$ & \\
\hline $\begin{array}{l}\text { Experience * research } \\
\text { organization }\end{array}$ & & & & & & & $\begin{array}{l}0.085^{* *} \\
(0.037)\end{array}$ \\
\hline Size & $\begin{array}{c}0.103^{* *} \\
(0.043)\end{array}$ & $\begin{array}{l}0.072 * * \\
(0.043)\end{array}$ & $\begin{array}{l}0.094^{* *} \\
(0.043)\end{array}$ & $-0.013(0.051)$ & $\begin{array}{l}0.073^{*} \\
(0.043)\end{array}$ & $\begin{array}{l}0.094^{* *} \\
(0.043)\end{array}$ & $\begin{array}{l}0.100^{* *} \\
(0.045)\end{array}$ \\
\hline Age & $\begin{array}{l}-0.011 \\
(0.007)\end{array}$ & $\begin{array}{l}-0.007 \\
(0.198)\end{array}$ & $\begin{array}{l}-0.007 \\
(0.007)\end{array}$ & $\begin{array}{c}0.004 \\
(0.009)\end{array}$ & $\begin{array}{l}-0.007 \\
(0.007)\end{array}$ & $\begin{array}{l}-0.010 \\
(0.007)\end{array}$ & $\begin{array}{l}-0.011 \\
(0.007)\end{array}$ \\
\hline RD_exp & $\begin{array}{c}0.375^{* * *} \\
(0.091)\end{array}$ & $\begin{array}{l}0.415^{* * *} \\
(0.090)\end{array}$ & $\begin{array}{l}0.371^{* * *} \\
(0.091)\end{array}$ & $\begin{array}{l}0.589 * * * \\
(0.107)\end{array}$ & $\begin{array}{l}0.410^{* * *} \\
(0.090)\end{array}$ & $\begin{array}{c}0.388 * * * \\
(0.091)\end{array}$ & $\begin{array}{l}0.399 * * * \\
(0.098)\end{array}$ \\
\hline $\begin{array}{l}\text { Likelihood-ratio test vs. } \\
\text { pooled: }\end{array}$ & 414.63 & 362.66 & 422.41 & 416.01 & 363.20 & 358.35 & 415.67 \\
\hline Number of Observation & 281 & 281 & 281 & 281 & 281 & 281 & 281 \\
\hline
\end{tabular}

According to Model 2, the functional diversity of the alliance portfolio in the value chain negatively affects innovation performance ( $p<0.05$; Not supporting Hypothesis 1$)$. In other words, if technology development-oriented and other functional types of alliances appeared at the same time in the portfolio, they had a negative effect on the innovation performance. The innovation performance of a company is usually created through R\&D. Therefore, if various types of partnerships are included in the portfolio, they seem to have a rather negative impact on innovation. According to previous studies, technologyoriented partnerships have higher innovation performance than marketing-oriented partnerships [63]. Additionally, innovation performance was high when the R\&D alliance ratio was high in the alliance portfolio [18].

In model 3, there was an inverted U-shaped relationship between the industrial diversity of the portfolio and innovation performance $(p<0.05, p<0.1$, respectively; supporting Hypothesis 2). A previous study insisted that positive effects of industry diversity constituting a portfolio were felt as increased diversity [68]. In addition, as the industry diversity of the alliance portfolio increased, the innovation performance increased at a certain level [29]. However, when the industry diversity increased above a certain level, the innovation performance started to decrease. This was because companies' absorption capacity was not enough to use various types of knowledge effectively.

Model 4 is the result of analyzing the positive effect of the firm's alliance management capability on innovation performance ( $p<0.01$; supporting Hypothesis 3$)$. The experience 
of firm alliance was reduced to a certain level, but when it was above a certain level, it affected innovation performance positively. This can be seen in terms of mutual credibility with the alliances claimed by Gulati [69]. Alliances basically lead to opportunistic behavior of the partners, which can generate costs and reduce benefits. Additionally, the firms' ability to foster relationships is related to the relational capabilities and alliances [32]. However, firms adopting open innovation must have the absorptive ability to leverage external knowledge and turn it into performance [70].

However, if firms have a long experience of partnership, mutual trust can be fostered based on the partners' knowledge, which can enhance innovation performance by alliance. Therefore, until the company has a certain level of partnership experience, the innovation performance is reduced through trial and error. However, if the company has a certain level of experience, it can generate more results based on mutual trust and knowledge.

In Model 2,3, and 4, the participation of research organizations in the alliance portfolio showed a positive effect. This could suggest that companies could improve the innovation performance of their alliance portfolios by acquiring the latest technology knowledge and research human resources, as suggested by previous studies $[5,37,44]$. This study also examined how the affiliation of research organizations in the portfolio affects functional diversity in the value chain, industrial diversity, and alliance management capability (Models 5-7). It was confirmed that the participation of research organizations positively influenced innovation performance by moderating functional diversity in the value chain and alliance management capability in Model 5 and $7(p<0.1, p<0.05$; supporting Hypothesis $4 \mathrm{a}, \mathrm{c}$; not supporting Hypothesis $4 \mathrm{~b}$ ). When research organizations participate in an alliance portfolio, companies can learn the latest technologies and use the workforce of the research organizations, as George et al. and other researchers have insisted $[9,37,71]$.

From Model 6, the value of functional diversity in the value chain changed to have a positive effect by interacting with research organizations. In addition, partnerships with research organizations positively influence innovation performance by moderating alliance management capability. This suggests that even though the alliance management capability of precision medicine companies is lacking, collaboration with research organizations is a good way to create innovation performance.

\section{Conclusions and Future Work}

This study investigated the current status of alliance portfolios of precision medical companies and examined the relationship between the diversity factors of alliance portfolios and corporate innovation performance with alliance management capability. It derived keywords by analyzing previous reports to derive the precision medical companies, and derived the alliance information from the Medtrack database and financial information from the WRDS and Orbis databases. Empirical analysis showed that the functional diversity in the value chain that constituted the alliance portfolio had a negative effect on the innovation performance of the firm, industrial diversity had an inverted U-shaped effect, and the participation of research organizations had a positive effect. It was also found that alliance management capability had positive effect. Moreover, it was found that there was an interaction of functional diversity in value chain and participation of research organizations, and alliance management capability and participation of research organizations in the alliance portfolio.

Therefore, this study provides the following implications. First, precision medicine companies should concentrate on R\&D alliances rather than considering functional diversity in order to improve innovation performance. Definitely, precision medicine firms should utilize intermediary ideas through production or marketing alliances to enhance innovation performance based on user participation. However, it seems that such translational research is not active yet. Previous study suggested that in the case of the Korean bio industry, bio companies can be positively affected to innovation performance in the upstream alliance with universities, the horizontal alliance with other companies, as well as the downstream alliance with pharmaceutical companies [72]. As such, the precision 
medicine firms can also enhance innovation performance at a more translational level through functional diversity in the value chain.

Second, precision medicine firms should be cautious to have various alliances with organizations in various industrial fields, because of the limitations of their ability to manage resource orchestration and alliances. Firm's resources are limited. Although corporate diversification can have a positive effect on innovation performance [73], an increase above the critical point of unrelated diversification can cause a shortage of resources and negatively affect innovation performance. Furthermore, as the complexity of the alliance increases, resources must be consumed for more alliance management capabilities. Therefore, despite the emphasis on convergence in the precision medical field, precision medicine companies must carry forward alliance in consideration of industrial diversity.

Third, precision medicine companies maximize cooperation with research organizations for innovation performance, which can improve limitations on it arising from form diversity of alliance and alliance management capability. Precision medical technology has many cumulative characteristics. Due to this point, it would be a desirable strategy to enhance innovation performance for a company to expand alliances with research institutes with technological capabilities, who have been continuously conducting the research in one field for a long time [74]. Furthermore, this study proved that the alliance with the research organization contributes to the positive effect of the interaction between functional diversity and alliance management capability on the innovative performance. This result implies that it can be an important "multidexterity" strategy for precision medicine companies to reduce risk in their business operations [75]. Therefore, it is necessary to pay attention to the composition of the alliance portfolio with research institutes as a catalyst for enhancing innovation performance.

This study provides information on the alliance portfolio factors that affect the innovation performance of precision medical companies. However, this study did not consider factors such as the company's ability to operate its own alliance portfolio, the resources and capabilities of partner companies, and the strength of relationships with partners. In addition, the rapid change of technology due to the emergence of precision medical care and structural factors of the network of precision medical companies could affect innovation performance. Therefore, further studies should be carried out to consider the specific factors and social network structure of precision medical companies. Additionally, future studies will require further analysis in light of the following: in this study, the company's innovation performance was set as a patent. It is because the number of patents can reflect firm's inventive activities [47]. However, average citations for patents, such as Citation Per Patent (CPP), can also be used to measure a company's innovation. CPP can be used to measure the technical capabilities of a patent [76]. Additionally, the reason for constructing an alliance portfolio is to improve financial performance in addition to innovative performance, so it is possible to analyze the performance obtained through marketing or production alliances by adding it to the dependent variable in future studies. Moreover, the dependent variable was the number of patents created in the year following the formation of the alliance portfolio. Studies claimed that the time lag between R\&D input and performance creation was less than 1 year or 1 year to 2 years, so this study was also set to 1 year $[50,51]$. However, in the future research, it is necessary to add time to analyze and compare results by increasing the time lag between R\&D input and creation of performances. In addition, further studies will be able to examine the effect of regional diversity on technology alliances. As firms want to be geographically dispersed and acquire external knowledge, not only inter-industry convergence but also inter-national cooperation is taking place $[28,77]$. Therefore, it may be proposed to analyze regional (national) diversity of partners in alliance portfolios in future research.

Author Contributions: Conceptualization, Y.C. and K.S.; methodology, K.S.; data curation, Y.C.; formal analysis, Y.C.; validation, K.S.; writing-original draft preparation, Y.C.; writing-review and editing, K.S.; supervision, K.S.; project administration, K.S. Both authors have read and agreed to the published version of the manuscript. 
Funding: This research received no external funding.

Institutional Review Board Statement: Not applicable.

Informed Consent Statement: Not applicable.

Data Availability Statement: Restrictions apply to the availability of some data. Data was obtained from Medtrack, WRDS, and Bureau van Dijk Orbis database, and are available with the permission of organizations to hold the data. In the case of patent data, it is freely accessible from the institution's database (USPTO etc.).

Conflicts of Interest: The authors declare no conflict of interest.

\section{References}

1. Hudson, K.; Lifton, R.; Patrick-Lake, B.; Burchard, E.G.; Coles, T.; Collins, R. The Precision Medicine Initiative Cohort ProgramBuilding a Research Foundation for 21st Century Medicine; Precision Medicine Initiative (PMI) Working Group Report to the Advisory Committee to the Director; National Institutes of Health: Bethesda, MD, USA, 2015.

2. Collins, D.C.; Sundar, R.; Lim, J.S.; Yap, T.A. Towards precision medicine in the clinic: From biomarker discovery to novel therapeutics. Trends Pharmacol. Sci. 2017, 38, 25-40. [CrossRef]

3. Mirnezami, R.; Nicholson, J.; Darzi, A. Preparing for precision medicine. N. Engl. J. Med. 2012, 366, 489-491. [CrossRef]

4. Pisano, G.P. Science Business: The Promise, the Reality, and the Future of Biotech; Harvard Business School Press: Boston, MA, USA, 2006.

5. George, G.; Shaker, A.Z.; Kathleen, K.W.; Khan, R. The effects of alliance portfolio characteristics and absorptive capacity on performance: A study of biotechnology firms. J. High Technol. Manag. Res. 2002, 12, 205-226. [CrossRef]

6. Jiang, R.J.; Tao, Q.T.; Santoro, M.D. Alliance portfolio diversity and firm performance. Strateg. Manag. J. 2010, 31, 1136-1144. [CrossRef]

7. Wuyts, S.; Dutta, S. Benefiting from alliance portfolio diversity: The role of past internal knowledge creation strategy. J. Manag. 2014, 40, 1653-1674. [CrossRef]

8. Pokorska-Bocci, A.; Stewart, A.; Sagoo, G.S.; Hall, A.; Kroese, M.; Burton, H. ‘Personalized medicine': What's in a name? Pers. Med. 2014, 11, 197-210. [CrossRef] [PubMed]

9. PCAST. Priorities for Personalized Medicine; Report of the President's Council of Advisors on Science and Technology; US President's Council of Advisors on Science and Technology: Washington, DC, USA, 2008.

10. PWC. The New Science of Personalized Medicine: Translating the Promise into Practice; Price Water House Coopers: Newark, DE, USA, 2009.

11. National Research Council. Toward Precision Medicine: Building a Knowledge Network for Biomedical Research and a New Taxonomy of Disease; The National Academies Press: Washington, DC, USA, 2011.

12. Prahalad, C.; Hamel, G. The core competence of the corporation. Harv. Bus. Rev. 1990, 68, 79-91.

13. Teece, D.J.; Pisano, G.; Shuen, A. Dynamic capabilities and strategic management. Strateg. Manag. J. 1997, 18, 509-533. [CrossRef]

14. Amit, R.; Schoemaker, P.J.H. Strategic assets and organizational rent. Strateg. Manag. J. 1993, 14, 33-46. [CrossRef]

15. Mahoney, J.T.; Pandian, J.R. The resource-based view within the conversation of strategic management. Strateg. Manag. J. 1992, 13, 363-380. [CrossRef]

16. Ramanathan, K.; Seth, A.; Thomas, H. Explaining joint ventures: Alternative theoretical perspectives. In Cooperative Strategies: Volume 1. North American Perspectives; Beamish, P.W., Killing, J.P., Eds.; New Lexington Press: San Francisco, CA, USA, 1997; pp. 51-85.

17. Das, T.K.; Teng, B.S. A resource-based theory of strategic alliances. J. Manag. 2000, 26, 31-61. [CrossRef]

18. Lin, C.H.; Wu, Y.J.; Chang, C.C.; Wang, W.H.; Lee, C.Y. The alliance innovation performance of R\&D alliances-the absorptive capacity perspective. Technovation 2012, 32, 282-292.

19. De Faria, P.; Lima, F.; Santos, R. Cooperation in innovation activities: The importance of partners. Res. Policy 2010, $39,1082-1092$. [CrossRef]

20. Macklis, R.M.; Sharma, N. Convergence technology in cancer medicine. Expert Rev. Med. Devices 2011, 8, 263-273. [CrossRef]

21. Moon, H.; Lee, S. Vertical alliance portfolios and the business performance of small technology-based firms. Technol. Anal. Strateg. Manag. 2017, 29, 462-475. [CrossRef]

22. Hamel, G.; Doz, Y.L.; Prahalad, C.K. Collaborate with your competitors and win. Harv. Bus. Rev. 1989, 67, 133-139.

23. Nelson, R.R. Why do firms differ, and how does it matter? Strateg. Manag. J. 1991, 12, 61-74. [CrossRef]

24. Rumelt, R.P.; Schendel, D.; Teece, D.J. Strategic management and economics. Strateg. Manag. J. 1991, 12, 5-29. [CrossRef]

25. Dussauge, P.; Garrette, B.; Mitchell, W. Learning from competing partners: Outcomes and durations of scale and link alliances in Europe, North America and Asia. Strateg. Manag. J. 2000, 21, 99-126. [CrossRef]

26. Santoro, M.D.; McGill, J.P. The effect of uncertainty and asset co specialization on governance in biotechnology alliances. Strateg. Manag. J. 2005, 26, 1261-1269. [CrossRef]

27. Roth, K.; O’Donnell, S. Foreign subsidiary compensation strategy: An agency theory perspective. Acad. Manag. J. 1996, 39, 678-703. 
28. Goerzen, A.; Beamish, P.W. The effect of alliance network diversity on multinational enterprise performance. Strateg. Manag. J. 2005, 26, 333-354. [CrossRef]

29. Marhold, K.; Kim, M.; Kang, J. The effects of alliance portfolio diversity on innovation performance: A study of partner and alliance characteristics in the bio-pharmaceutical industry. Int. J. Innov. Manag. 2017, 21, 1-24. [CrossRef]

30. Martinez, M.; Zouaghi, F.; Garcia, M. Capturing value from alliance portfolio diversity: The mediating role of R\&D human capital in high and low tech industries. Technovation 2017, 59, 55-67.

31. Yoon, S.; Jo, G.; Kang, J. Alliance portfolios and firm performance: Focusing on the interaction between resources and bargaining power. Int. Bus. J. 2015, 26, 63-97. [CrossRef]

32. Leitao, J.; Pereira, D.; Brito, S. Inbound and outbound practices of open innovation and eco-innovation: Contrasting bioeconomy and non-bioeconomy firms. J. Open Innov. Technol. Mark. Complex. 2020, 6, 145. [CrossRef]

33. Rocha-Goncalves, F.; Gonçalves, V.D.C. The role of the alliance management capability. Serv. Ind. J. 2011, 31, 1961-1978. [CrossRef]

34. Duysters, G.; Heimeriks, K.H.; Lokshin, B.; Meijer, E.; Sabidussi, A. Do firms learn to manage alliance portfolio diversity? The diversity-performance relationship and the moderating effects of experience and capability. Eur. Manag. Rev. 2012, 9, 139-152. [CrossRef]

35. Hoang, H.; Rothaermel, F.T. The effect of general and partner-specific alliance experience on joint R\&D project performance. Acad. Manag. J. 2005, 48, 332-345.

36. Ireland, R.D.; Hitt, M.A.; Vaidyanath, D. Alliance management as a source of competitive advantage. J. Manag. 2002, 28, 413-446. [CrossRef]

37. Rothaermel, F.M.; Deeds, D. Alliance type, alliance experience and alliance management capability in high-technology ventures. J. Bus. Ventur. 2006, 21, 429-460. [CrossRef]

38. Findikoglu, M.; Lavie, D. The contingent value of the dedicated alliance function. Strateg. Org. 2019, 17, 177-209. [CrossRef]

39. Shukla, D.M.; Mital, A. Effect of firm's diverse experiences on its alliance portfolio diversity: Evidence from India. J. Manag. Org. 2018, 24, 748-778. [CrossRef]

40. Cho, S.Y.; Arthurs, J.D. The influence of alliance experience on acquisition premiums and post-acquisition performance. J. Bus. Res. 2018, 88, 1-10. [CrossRef]

41. Huang, K.F. Antecedents for forming simultaneous alliances or one-by-one alliances. Ind. Corp. Chang. 2017, 26, 73-101. [CrossRef]

42. Culpan, R. Open Innovation through Strategic Alliances: Approaches for Product, Technology, and Business Model Creation; Palgrave Macmillan: New York, NY, USA, 2014.

43. Zucker, L.G.; Darby, M.R. Capturing technological opportunity via Japan's star scientists: Evidence from Japanese firms' biotech patents and products. J. Technol. Transf. 2001, 26, 37-58. [CrossRef]

44. Silva, M.J.; Leitao, J. Cooperation in innovation practices among firms in Portugal: Do external partners stimulate innovative advances? Int. J. Entrep. Small Bus. 2009, 7, 391-403. [CrossRef]

45. Moon, S.; Jang, K.; Kim, H. Success strategy of precision medicine. Korea Inst. Sci. Technol. Eval. Plan. $2016,15,14-32$.

46. Ministry of Health and Welfare. Developed Precision Medical Technology Based on Genome: Health-ICT Convergence; Ministry of Health and Welfare: Sejong, Korea, 2016.

47. Laursen, K.; Salter, A. Open for innovation: The role of openness in explaining innovation performance among UK manufacturing firms. Strateg. Manag. J. 2006, 27, 131-150. [CrossRef]

48. Branch, B. R\&D activity and profitability: A distributed lag analysis. J. Political Econ. 1974, 82, 999-1011.

49. Pakes, A.; Griliches, Z. Patents and R\&D at the firm level: A first look. In RED, Patents, and Productivity; Griliches, Z., Ed.; The University of Chicago Press: Chicago, IL, USA, 1984; pp. 55-72.

50. Lee, H.; Baek, C.; Lee, J. Analysis on time lag effect of firm's R\&D investment. J. Technol. Innov. 2014, 22, 1-22.

51. Kim, G.; Kim, G. A study on the relation between R\&D investment and patent in Korean pharmaceutical industry. Korean J. Health Econ. Policy 2016, 22, 21-38.

52. Gulati, R. Social structure and alliance formation patterns: A longitudinal analysis. Admin. Sci. Q. 1995, 40, 619-652. [CrossRef]

53. Lee, C. Strategic alliances influence on small and medium firm performance. J. Bus. Res. 2007, 60, 731-741. [CrossRef]

54. Champonnois, S. What Determines the Distribution of Firm Sizes? Working Paper; Mimeo, UCSD: San Diego, CA, USA, 2008.

55. Thornhill, S.; Amit, R. Learning about failure: Bankruptcy, firm age, and the resource-based view. Org. Sci. 2003, 14, 497-509. [CrossRef]

56. Gittelman, M.; Kogut, B. Does good science lead to valuable knowledge? Biotechnology firms and the evolutionary logic of citation patterns. Manag. Sci. 2003, 49, 366-382. [CrossRef]

57. Lahiri, N.; Narayanan, S. Vertical integration, innovation, and alliance portfolio size: Implications for firm performance. Strateg. Manag. J. 2013, 34, 1042-1064. [CrossRef]

58. Leeuw, T.; Lokshin, B.; Duysters, G. Returns to alliance portfolio diversity: The relative effects of partner diversity on firm's innovative performance and productivity. J. Bus. Res. 2014, 67, 1839-1849. [CrossRef]

59. Huang, K.; Lin, K.; Wu, L.; Yu, P. Absorptive capacity and autonomous R\&D climate roles in firm innovation. J. Bus. Res. 2015, 68, 87-94.

60. Baum, J.A.C.; Calabrese, T.; Silverman, B.S. Don't Go It Alone: Alliance Network Composition and Startups' Performance in Canadian Biotechnology. Strateg. Manag. J. 2000, 21, 267-294. [CrossRef] 
61. Reuer, J.J.; Park, K.M.; Zollo, M. Experiential Learning in International Joint Ventures: The Roles of Experience Heterogeneity and Venture Novelty; INSEAD: Fontainebleau, France, 2002.

62. Mowery, D.C.; Oxley, J.E.; Silverman, B.S. Strategic alliances and interfirm knowledge transfer. Strateg. Manag. J. 1996, 17, 77-91. [CrossRef]

63. Hagedoorn, J.; Schakenraad, J. The effect of strategic technology alliances on company performance. Strateg. Manag. J. 1994, 15, 291-309. [CrossRef]

64. McGee, J.E.; Dowling, M.J. Using R\&D cooperative arrangements to leverage managerial experience: A study of technologyintensive new ventures. J. Bus. Ventur. 1994, 9, 33-48.

65. McGee, J.E.; Dowling, M.J.; Meggingson, W. Cooperative strategy and new venture performance: The role of business strategy and management experience. Strateg. Manag. J. 1995, 16, 565-580. [CrossRef]

66. Mitchel, W.; Shaver, J.; Yeung, B. Performance following changes of international presence in domestic and transition industries. J. Int. Bus. Stud. 1993, 24, 647-669. [CrossRef]

67. Song, J.; Kim, H. Knowledge transfer and acquisition through strategic alliances: A study of Asian firms' strategic alliances in the high-tech sector. J. Strateg. Manag. 2007, 10, 1-18. [CrossRef]

68. Deeds, D.L.; Hill, C.W.L. Strategic alliances and the rate of new product development: An empirical study of entrepreneurial biotechnology firms. J. Bus. Ventur. 1996, 11, 41-55. [CrossRef]

69. Gulati, R. Alliances and networks. Strateg. Manag. J. 1998, 19, 293-317. [CrossRef]

70. Lichtenthaler, U.; Lichtenthaler, E. A capability-based framework for open innovation: Complementing absorptive capacity. J. Manag. Stud. 2009, 46, 1315-1338. [CrossRef]

71. De las Heras-Rosas, C.; Herrera, J. Research trends in open innovation and the role of the university. J. Open Innov. Technol. Mark. Complex. 2021, 7, 29. [CrossRef]

72. Shin, K.; KIM, S.J.; PARK, G. How does the partner type in R\&D alliances impact technological innovation performance? A study on the Korean biotechnology industry. Asia Pac. J. Manag. 2016, 33, 141-164.

73. Yeom, K.; Song, C.; Shin, K.; Choi, H.S. What Is Important for the Growth of Latecomers in the Medical Device Industry? J. Open Innov. Technol. Mark. Complex. 2021, 7, 13. [CrossRef]

74. Valdez-Juárez, L.E.; Castillo-Vergara, M. Technological Capabilities, Open Innovation, and Eco-Innovation: Dynamic Capabilities to Increase Corporate Performance of SMEs. J. Open Innov. Technol. Mark. Complex. 2021, 7, 8. [CrossRef]

75. Robbins, P.; O'Gorman, C.; Huff, A.; Moselein, K. Multidexterity-A New Metaphor for Open Innovation. J. Open Innov. Technol. Mark. Complex. 2021, 7, 99. [CrossRef]

76. Jeong, H.; Ko, Y. Configuring an alliance portfolio for eco-friendly innovation in the car industry: Hyndai and Toyota. J. Open Innov. Technol. Mark. Complex. 2016, 2, 1-16. [CrossRef]

77. Belderbos, R.; Jacob, J.; Lokshin, B. Corporate venture capital (CVC) investments and technological performance: Geographic diversity and the interplay with technology alliances. J. Bus. Ventur. 2018, 33, 20-34. [CrossRef] 